\title{
Shaping Professional Identity Through Professional Development: A Retrospective Study of TESOL Professionals
}

\author{
Hussain Ahmad ${ }^{1}$, Fatmawati Latada ${ }^{2}$, Muhammad Nubli Wahab ${ }^{2}$, Sayyed Rashid Shah ${ }^{3}$ \& Khushnoor Khan ${ }^{4}$ \\ ${ }^{1}$ English Language Institute, King Abdul-Aziz University, Jeddah, Saudi Arabia \\ ${ }^{2}$ Centre for Modern Languages and Human Sciences, University of Malaysia Pahang (UMP), Malaysia \\ ${ }^{3}$ Graduate School of Education, University of Exeter, Exeter, UK \\ ${ }^{4}$ Department of Statistics, Faculty of Sciences, King Abdul-Aziz University, Jeddah, Saudi Arabia \\ Correspondence: Hussain Ahmad, English Language Institute, King Abdul-Aziz University, Jeddah 21589, \\ Saudi Arabia. Tel: 966-591-693-221. E-mail: hahmad.me@gmail.com
}

Received: June 5, 2018 Accepted: June 27, 2018 Online Published: July 28, 2018

doi:10.5539/ijel.v8n6p37 URL: https://doi.org/10.5539/ijel.v8n6p37

\begin{abstract}
In an educational milieu student learning outcomes are directly related to teacher professional identity (TPI) i.e. improvement in the TPI will bear a direct positive effect on the learners' academic achievements. Current study focuses on the development of TPI of English as a Foreign Language Teacher at English Language Institute (ELI) of a Saudi Arabian university through an in-service Cambridge English Teachers (CET) Professional Development (PD) program (CET-PD). Five determinants of TPI - Knowledge of Teaching Context (KCT), Collegial Collaboration (CC), Teaching Practices (TPS), Teacher Self-Efficacy (TSE), and Teacher Agency (TA) were studied before and after the PD program. Retrospective pretest-posttest research design was employed for addressing the research question: whereas responses on the five determinants were elicited from 120 participants through a self-administered questionnaire before and after the CET-PD program. Due to non-normality of data, a non-parametric statistic test-Wilcoxon signed Rank test was employed to analyze the collected data using SPSS. Results of the study revealed that three determinants of TPI - KCT, TSE, and TPS exhibited larger differences; whereas, for $C C$ the differences were moderate and for $T A$ the differences were minimal. By and large, due to in-service CET- PD program TPI exhibited improvement. The results of the study will be beneficial for teacher trainers to focus more on the teachers' awareness of the learners' and institutional contextual knowledge in a culture embedded in conservative norms. This study is a part of the quantitative phase of an ongoing Ph.D. project which employs mixed method convergent design.
\end{abstract}

Keywords: attributes of professional identity, EFL teacher professional identity, professional development, Retrospective Pretest-Posttest (RPP) Study

\section{Introduction}

In the backdrop of the current rapid socio-cultural and socio-economic changes in Saudi Arabia, English Language Institute (ELI) of a Saudi Arabian university has introduced a reform agenda to enhance English language learners' learning outcomes and improve institutional performance. The first step taken in this direction was the initiation of Cambridge English Teacher (CET) professional development (PD) program to diversify English as a Foreign Language (EFL) teachers' evidence-based instructional practices and to support them with meeting their learners' ever-emerging learning needs. In fact, to keep abreast with the advances in the field of ELT and remain current on the increasing amount of research, EFL teachers need effective professional development. "One incessant finding in the research literature is that notable improvements in education almost never take place in the absence of professional development" (Gusky, 2000, p. 4). Therefore, the CET PD took place at an opportune time when ELI is introducing an "ELI method" keeping in view the contextual requirements. The CET PD program included face-to-face training sessions, homework assignments, online courses, and online discussion forums. CET PD program aims at "tackling up-to-date language teaching topics with a contextualized focus to display best practices in the field" (Princess Nourah University's English Language Program, 2017). It has been observed that CET PD plays an instrumental role in shaping teaching practices and anchoring teachers' beliefs, as in the process of education reformism teachers' identity is always at 
the cusp of change (Ronnie, 2013). A primary focus of any PD program is the development of teacher professional identity (TPI) (Danielewicz, 2001; Norton, 2001; Johnson, 2009). The objective of this study, therefore, is to investigate whether CET PD has enhanced the EFL TPI in a Saudi context.

Professional development, being a socio-cultural phenomenon, is a site where language teachers not only deepen their pedagogical content knowledge (PCK) but also reshape their professional identity (Borg, 2017). Depending on how they view themselves and want to be viewed by others, teachers develop their teaching identities in their teaching contexts (Clarke, 2008) through interaction with other teachers, students, administration and the teaching methods and materials. However, with the notable improvements in education, teachers are not defined merely by their content and pedagogical knowledge; rather they are perceived in a wider socio-professional role (Freeman, 2009). Due to its fluid and complex nature, language teacher identity is developed by multiple underlying factors; however, different socio-professional encounters enact different aspects of an EFL TPI (Burkhuizen, 2017). A socially constructed EFL TPI in PD comprises the following interlinked attributes: (I) teaching context (Miller, 2009), (II) collegial interaction (Pennington and Richards, 2016), (III) classroom practices (Swan, 2015) (IV) teacher self-efficacy (TSE) (Kelchtermans, 2009; Phil, 2017), and (V) language teacher agency (Miller, 2009). The current study investigates how the above constituent elements of EFL TPI are developed as a result of the CET PD course.

Professional learning in the form of PD and professional identity are inextricably connected (Robinson, 2014); therefore, the current quantitative study will explore how the EFL TPI is re-constructed in an in-service PD program. The current study will also contribute to the EFL TPI development process in a Saudi context. This study proved a compliment as well as a revealing contrast to what exists in the predominant literature by answering the following research question:

1) Does the Cambridge English Teacher (CET) PD course have an impact on the TPI of in-service EFL instructors at a Saudi Arabian university?

\section{Literature Review}

\subsection{Teacher Professional Identity}

The notion we do what we think is the basis of how PD influences professional identity (Watson, 2006). TPI development is built on the premise that individuals formulate and construct their identities to shape their self-perception on coherent and positive lines (Alvesson, Ashcraft, \& Thomas, 2008). Being a dynamic attribute, TPI is responsive to many factors inside and outside the classroom; however, the alignment between PD experiences and TPI development serves as an illuminating process. Teacher identity construction is a multi-facetted and a complex process where teacher continuous learning is emphasized. For instance, EFL TPI is constantly evolved and developed in PD experiences (Mora, Trejo, \& Roux, 2014). Furthermore, Van Huizen, Van Oers and Wubbels (2005) believe that teacher education and professional development, from the Vygotskian perspective, "is best conceived as the development of professional identity" (p. 275). Similarly, Nesje, Carinus, and Strype (2018) found out that the teachers' learning experiences in PD were perceived as identity reconstruction process while trying out to know their possible selves.

Teacher identity development, a complex phenomenon, is formed and garnered by a plethora of endorsing beliefs and influencing factors; however, different identity aspects enact during different encounters (Burkhuizen, 2017). Thus, for this study, five attributes of EFL TPI are studied about PD programs. These attributes are teaching context, collegial interaction, classroom practices, self-efficacy, and language teacher agency.

\subsubsection{Teaching Context}

Identity formation draws from the intriguing interplay of various internal and external factors; however, it is largely "dependent upon the contexts in which we immerse ourselves" (Rodgers \& Scott, 2008, p. 734). As teaching context is a dominant factor in TPI realignment (Pennington \& Richards, 2016), "different contexts for teaching create different potentials for learning that the teacher must come to understand" (Richards, 2012, p. 48). Along the same lines, Lave and Wenger's (1991) situated learning theory renders teacher identity change an imperceptible process in a specific teaching context (Flores \& Day, 2006). Augmenting this idea, Johnston (1997) claims that "in complex contexts in which personal, educational, political and socioeconomic discourses all influence the way the life is told" (p. 708). Being among the critical determinants of teacher identity shaping, contextual knowledge of the teaching arena and the students' culture is a fundamental segment of PD programs (Miller, 2009; Pennington \& Richards, 2016; Shirazi \& Bagheri, 2015).

A language teacher's contextual knowledge and awareness could be categorized into three broad categories: classroom level knowledge, institutional level knowledge, and knowledge of the teaching culture. Firstly, a 
language teacher's knowledge of the teaching context at the classroom level is characterized by his relationship with the learners as well as the choice teaching methodologies/philosophies. Building a strong rapport with the students rather than distancing from them provides a pleasurable basis for effective teaching and learning (Harizon, 2015). As for the teaching methodologies, it is not only based on the learners' socio-cultural demands (Sulaimani \& Elyas, 2015) but also is situated in the conception of "both global appropriacy and local appropriation" (Kramsch \& Sullivan, 1996, p. 199). Secondly, from the developmental constructive perspective teacher identity is socially constructed and is perfected through adherence to institutional policies and expectations (Garton, 2008). Therefore, teacher's knowledge of the context at institutional level means his broader relationships and his abidance of the institutional reform agenda and policies. Thirdly, knowing the culture where teaching and learning take place is a primordial aspect of teacher identity. Ahmad (2015), for example, delineated that English language teacher identity formation is related to the societal perceptions toward English language. Thus, these assumptions have an embedded drive for the inclusion of context awareness in PD programs. No known study in the EFL context has investigated the accumulative effect of the teaching context knowledge on teacher professional identity.

\subsubsection{Collegial Cooperation}

Identity formation is actualized "through engagement with others in cultural practice" (Smagorinsky, Cook, Moore, Jackson, \& Fry, 2004, p. 21). Being aware of the central importance of interconnectedness, language teachers "develop their identity as language teaching professionals in collaboration with those of other practitioners and the wider field" (Pennington \& Richards, 2016, p. 20). Locating the current study in socio-cultural perspective of human development, collaboration and relationship are honed in PD for the betterment of institutional culture and learners' achievement (Sarason, 1996; Desimone 2009). Given the significance of collaboration in professional development, achieving the common goal of students' learning is individual as well as a collective endeavor. Grodsky and Gamoran (2003) determine that creating a strong social bond and building communities for shared teaching values is one of the pillars of effective PD programs which is rooted in the students' needs and societal demands. Thus, PDis instrumental in shifting teachers' conceptions and preconceptions for the purpose of nurturing collegial relationship (Hofman \& Dijkstra, 2010; Ingravson, Meiers \& Beavis, 2005). Nevertheless, no familiar study has looked into how EFL teachers' collegial cooperation is garnered in professional development.

\subsubsection{Classroom Practices}

PD programs offer the process that both challenge and support professional teachers in shifting their classroom practices, and thus in constructing their teaching selves and professional identities (Rodgers \& Scott, 2008). However, across the Arab world and other EFL contexts in Far East Asia, the main culprit behind defective classroom practices and degenerative outdated teaching methodologies are ineffective PD agenda (Cheng, 2004; Fareh, 2010). Therefore, any PD program that cannot explicitly develop teachers' classroom practices and methodologies will fail to promote a reform agenda and cause a psychological shift in teachers' teaching perceptions.

For an EFL teacher, teaching practices is a conglomeration of practical and psychological processes that comprise teaching methodologies, classroom management skills, and contextualizing teaching methods (Richards, 2011). Dreil and Berry (2012) suggested that "professional development programs aimed at the development of teachers' PCK should be organized in ways that closely align to teachers' professional practice, including opportunities to enact certain instructional strategies and materials and to reflect, individually and collectively, on their experiences" (p. 27). Teaching methodology and philosophical outlook bestow on teachers a wider array of practices and concepts through which they see how their students' learning happens and how their professional identity burgeons (Richards, 2017; Pennington \& Richards, 2016). Since teaching methodology is a reflection of teachers' pedagogical beliefs and their opinions about the learning process; any PD efforts that claim teachers' enhanced productivity take the teaching methodology development as a priority. Dreil and Berry (2012) suggested that "professional development programs aimed at the development of teachers' PCK should be organized in ways that closely align to teachers' professional practice" (p. 27). Since no published study has probed the impact of an in-service PD on EFL teacher classroom practices in the Saudi Arabian context, this study will try to establish how TPI is reshaped in professional development.

\subsubsection{Self-Efficacy}

Of the five constructs that develop TPI in PD, (TSE) is the most prominent and overarching determinant drawing from and affecting all other teacher identity attributes (Kelchtermans, 2009). Self-efficacy denotes "beliefs in one's capabilities to organize and execute a course of action required to produce given attainment" (Bandura, 
1997, p. 3). In the context of the current study, TSE is defined as "the teacher's belief in his or her capability to organize and execute courses of action required to accomplish a specific teaching task in a particular context" (Tschannen-Moran, Hoy, \& Hoy, 1998, p. 233). Being solely context-driven, TSE not only affects students' learning outcome but influences teachers' motivation, collegiality, teaching philosophy and teacher agency. Although TSE is a product of the environment, Bandura (1977) contends that without an intervention TSE will not transform positively or negatively. In the same line of reasoning Onafowora (2005) believes that PD impacts TSE to enable teachers to transform theory into practice according to the teaching situation. Teacher self-efficacy, being a major construct of teacher professional identity, strongly impacts various aspects of teaching. Bandura (1993) explicates while linking TSE with students' achievements, "teachers' beliefs in their personal efficacy to motivate and promote student learning affect the type of learning environments they create and the level of academic progress their students achieve" (p. 117). As the existing research does not highlight TSE in Saudi EFL settings, this study will consider the impact of TSE on EFL teachers' identity formation.

\subsubsection{Teacher Agency}

Different psycho-social and physiological interpretations lend different connotations to the agency. Agency is an individual's control over his/her emotions, behavior, the consequences of various actions and the subsequent evaluation (Duranti, 2006). Teachers' agency, being caught between the free will and institutional shackles, refers to their power and freedom about the different dimensions of teaching profession (Vahasantanen, 2015) wherein they pursue their teaching goals within a context in the presence of internal and external forces. Owing to its central position in forming and developing teacher professional identity, teacher agency is an inseparable constituent of teacher PD endeavors (Miller, 2009; Mercelo, 2009).

Agentive actions in the broader educational setup lead teachers to have their say in all vistas of their professional life, from curriculum reforms to teaching processes to professional development. Teacher agency in curriculum reforms shifts the focus from looking outward to teaching content to providing the materials based on the learners' needs and learning styles, though the role of a professional textbook is not denied. Datnow, Hubbard and Mehan, (2002) opine that curriculum being a continuous effort based on daily teaching could be only learner-centered when teachers exercise their agency proactively. Moreover, involving teachers in curriculum designing lessens the theory-practice gap, as teachers teach what they believe in. Next, teachers' agencies come into play while they are employing a particular teaching method or approach based on the contextual requirement (Yang, 2015); since one-size fits formula that is thrust upon teachers does not often work. Lastly, Noonan (2016) asserts that teacher agency is often invoked when teachers choose their PD pathways. Thus, PD garners a psychological shift in teachers from being authored by external forces to authoring their agency and hence professional identity. Since no study has considered the above three aspects of teacher agency in relation to TPI development, the current study will investigate how PD program influence teacher agency.

\subsection{Conceptual Framework}

From the ongoing discussion, five determinants of the TPI can be exhibited graphically in Figure. 1. The current research studies the impact of five determinants of TPI individually and their impact on TPI collectively, before and after the CET-PD program.

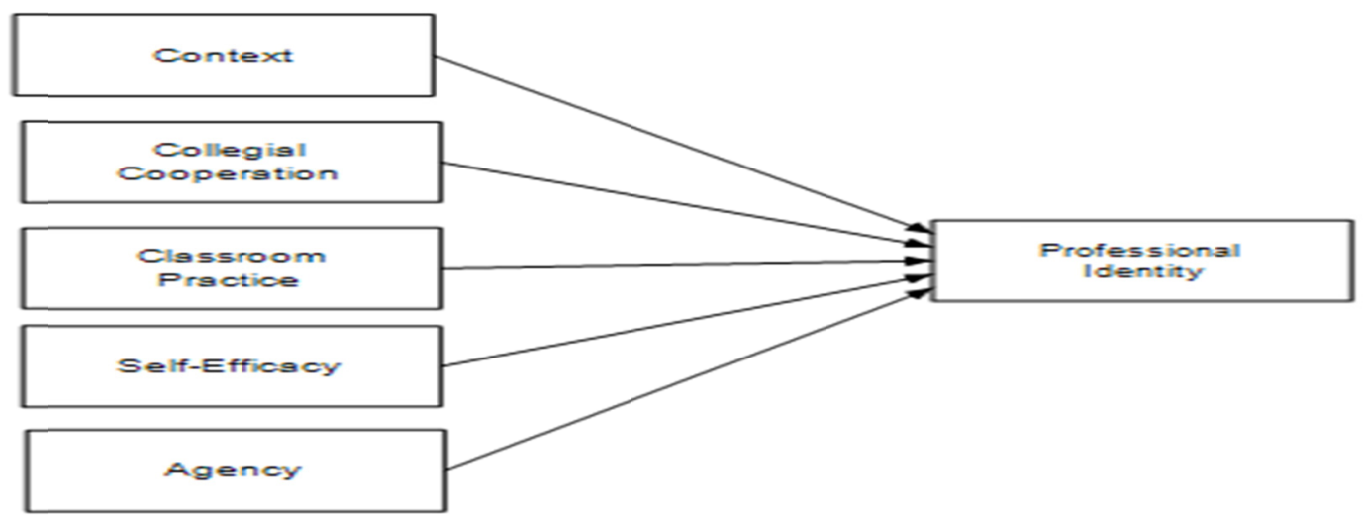

Figure 1. Five determinants of teacher professional identity 
In conclusion, the above five attributes of TPI have been the focus of nearly all PD efforts; however, the burgeoning of research in this area is based on theoretical assumptions or mere opinions rather than any empirical evidence both in mainstream education and ELT. Despite being significantly interlinked, the aforementioned five attributes have never been studied in a single study. Therefore, the current study, keeping in view the gap in the literature, explores the impact of in-service PD on the EFL TPI (TPI is represented by context, collegiality, classroom practice, self-efficacy, and agency).

\section{Methodology}

Retrospective pretest/posttest quantitative data survey method was employed to probe how EFL teachers' professional identity has been influenced as a result of an in-service PD program. A self-administered questionnaire was employed to investigate teacher identity change and also gave the opportunity to participants to reflect on the PD program they had recently participated in.

\subsection{Program Evaluated}

The Cambridge English Teacher (CET) PD program was evaluated using retrospective pretest/posttest design. The data were collected from all the EFL instructors $(N=120)$ of the English Language Institute (ELI) who participated in the CET PD program. The content of the PD program included teaching methodologies (differentiated instruction), classroom management, classroom interaction, giving instructions and teaching four skills (reading, writing, listening \& speaking). Furthermore, teaching vocabulary, using games in the classroom, learning strategies, student autonomy, students culture sensitivities, classroom observation, lesson planning, designing courses, adapting textbook materials, teacher collaboration, teachers' autonomy and agency, and outlining future PD goals were also included.

\subsection{Instrument and Procedure}

Since the five attributes being investigated in this study have never been explored in a single research, no quantitative tool was found in the literature to be utilized or adapted for the data collection in this study. Therefore, the main questionnaire used in this study is based on the literature review of EFL teachers' identity development and in-service professional development, the content of the CET course offered, and the principal author's personal experience as an EFL teacher and teacher trainer at the ELI. The main questionnaire, section B, measure the five teacher identity attributes. Responses of the participants were recorded on a five-point Likert scale ranging from 1 to 5 , with 1 measuring 'strong disagreement' and 5 'strong agreement' with the statements. To demonstrate instrument's reliability, Cronbach's alpha was calculated for the overall questionnaire as well as the five constructs: context, classroom practices, collegial cooperation, self-efficacy, and agency. The Cronbach's alpha statistics show strong internal consistency reliability $(\alpha=.954)$ of the overall survey items. The study was approved by the ethics committee at the ELI the site where data was collected.

\subsection{Retrospective Pretest-Posttest Research Design}

Retrospective pretest-posttest (RPP) design has gained tremendous popularity for measuring the impact of learning, such as PD programs. This design is a one-shot study wherein data are collected retrospectively from the participants' before and after attitudes, perceptions, beliefs and learning at the conclusion of the PD program (Russ-Eft \& Preskil, 2009). In the same tool, one rating refers to the self-report before the initiative whereas the second rating is about the perceptions and experiences after the initiative (Campbell \& Stanley, 1963).

The RPP method was used in this study because it has advantages over traditional pretest and posttest method. First, the RPP overcomes the response shift bias deficiency of the traditional pretest and posttest (Lamb \& Tschillard, 2005; Pratt, McGuigan, \& Katzev, 2000). The retrospective pre-test/post-test instrument is administered at the end of a program in which the responses in the form of self-report are contemporaneous. In contrast, the standard pre-test-post-test tools are implemented twice: one before the program and another after the program, thus giving rise to response shift bias because the participants at the pretest stage believe they know what they do not know. As well as studies have reported a higher validity measure for retrospective pre-test/post-test as compared to the standard pre-test-post-test (Moore \& Tananis, 2009; Hoogstraten, 1982). Finally, between the two methods, retrospective pre-test/post-test is more cost effective as the participants respond only one time (Neilson, 2011).

\subsection{Data Analysis}

Demographic data were analyzed using frequencies and central values. Data from the retrospective pretest-posttest were analyzed using descriptive statistics. To compare the pretest and posttest data, a non-parametric test, Wilcoxon signed rank test was employed after it was determined by applying Kolmogorov-Smirnov test that the data did not meet the normality assumption. Since the p-values of all the five 
attributes are less than 0.05 , the hypothesis of normality is rejected.

\section{Findings}

\subsection{Demographic Data of the Survey Participants}

Table 1 contains sampling characteristics, including age, academic credentials, Language teaching qualification, EFL experience, length of stay at the ELI and their linguistic background.

Table 1. Sampling characteristics $(N=120)$

\begin{tabular}{|c|c|c|c|}
\hline Sampling Characteristics & Categories & $\mathrm{N}$ & $\%$ \\
\hline \multirow{4}{*}{1} & $25-34$ & 13 & 10.8 \\
\hline & $35-44$ & 52 & 43.3 \\
\hline & $45-54$ & 46 & 38.3 \\
\hline & $55-64$ & 9 & 7.5 \\
\hline \multirow{3}{*}{ Highest Academic Credentials } & BA & 25 & 20.8 \\
\hline & MA & 76 & 63.3 \\
\hline & $\mathrm{PhD}$ & 19 & 15.8 \\
\hline \multirow{3}{*}{ EFL Qualification } & CELTA/DELTA & 39 & 32.5 \\
\hline & MA/BA TESOL & 59 & 49.2 \\
\hline & MA English & 22 & 18.3 \\
\hline \multirow{5}{*}{ EFL Experience } & $3-4$ years & 1 & 0.8 \\
\hline & $5-9$ years & 19 & 15.8 \\
\hline & $10-15$ years & 49 & 40.8 \\
\hline & $16-25$ years & 39 & 32.5 \\
\hline & $>25$ years & 12 & 10.0 \\
\hline \multirow{5}{*}{ LOS in ELI } & $1-2$ years & 12 & 10.0 \\
\hline & $3-4$ years & 16 & 13.3 \\
\hline & $5-9$ years & 60 & 50.0 \\
\hline & $10-15$ years & 30 & 25.0 \\
\hline & $>15$ years & 2 & 1.7 \\
\hline \multirow{3}{*}{ Linguistic Background } & NS & 25 & 20.8 \\
\hline & NNAS & 42 & 35.0 \\
\hline & NNNAS & 53 & 44.2 \\
\hline
\end{tabular}

Note. NS $=$ Native Speakers, NNAS= Non-Native Arabic Speakers, NNNAS= Non-Native Non-Arabic Speakers, LOS= Length of Stay.

The respondents who participated in the CET course ranged in age from 25 to 64 with a median age range of $35-44$. The vast majority of the participants $(n=100)$ were in the 35-54 age range. Of 120 participants, $24(21.3 \%)$ had BA, 77 (63.1\%) had MA, and 19 (15.6\%) had PhD. Of 120 participants who participated in this study, 39 (32.5\%) had CELTA or DELTA or both, 59 (49.2\%) had MA TESOL/Applied Linguistics, BA TESOL/Applied Linguistics or both as ELT qualification. The remaining participants $22(18.3 \%)$ had MA English Language or MA English Language and Literature.

Of 120 participants, 12 (10\%) had more than 25 years, 39 (32.5\%) had 16-25 years, 49 (40.8\%) had 10-15 years, $19(15.8 \%)$ had 5-9 years, and only $1(8.0 \%)$ had 3-4 years of EFL teaching experience. Their median experience range is $10-15$ years with the vast majority $(\mathrm{n}=88)$ having $10-25$ years of teaching English as a foreign language experience. The 120 participants who responded, 2 (1.7\%) had more than 15 years, $30(25 \%)$ had $10-15$ years, 60 $(50 \%)$ had 5-9 years, $16(13.3 \%)$ had 3-4 years, and $12(10 \%)$ had $1-2$ years teaching experience at the ELI. The data indicates half of the participants had the ELI experience in the range of 5-9 years. Of 120 participants, 25 $(20.8 \%)$ were native speakers, $42(35 \%)$ were non-native Arabic speakers, and $53(44.2 \%)$ were non-native non-Arabic speakers. Of those who responded, more than $50 \%$ are non-native non-Arabic speakers. The researcher belongs to the last category. 


\subsection{Descriptive Statistics}

Table 2. Teachers' knowledge of the teaching context before and after the CET

\begin{tabular}{|c|c|c|c|c|c|c|c|c|c|c|c|}
\hline & \multirow{2}{*}{$\begin{array}{l}\text { Context } \\
\text { Before/After }\end{array}$} & \multicolumn{2}{|c|}{ S.D } & \multicolumn{2}{|c|}{ Disagree } & \multicolumn{2}{|c|}{ Neutral } & \multicolumn{2}{|c|}{ Agree } & \multicolumn{2}{|c|}{ S.A } \\
\hline & & $\mathrm{n}$ & $\%$ & $\mathrm{n}$ & $\%$ & $\mathrm{n}$ & $\%$ & $\mathrm{n}$ & $\%$ & $\mathrm{n}$ & $\%$ \\
\hline \multirow{5}{*}{ Before } & I am aware of my learners' cultural sensitivities. & 4 & 3.3 & 7 & 5.8 & 15 & 12.5 & 39 & 32.5 & 55 & 45.8 \\
\hline & I can adapt to new policy changes at the ELI. & 1 & 0.8 & 11 & 9.2 & 22 & 18.3 & 45 & 37.5 & 41 & 34.2 \\
\hline & $\begin{array}{l}\text { I learn from my colleagues who come from } \\
\text { diverse cultural and academic backgrounds. }\end{array}$ & 4 & 3.3 & 10 & 8.3 & 27 & 22.5 & 50 & 41.7 & 29 & 24.2 \\
\hline & $\begin{array}{l}\text { I know how the English language is perceived in } \\
\text { Saudi Arabian society. }\end{array}$ & 3 & 2.5 & 10 & 8.3 & 17 & 14.2 & 52 & 43.3 & 38 & 31.7 \\
\hline & I can develop a good rapport with my learners. & 2 & 1.7 & 8 & 6.7 & 13 & 10.8 & 25 & 20.8 & 72 & 60.0 \\
\hline \multirow{5}{*}{ After } & I am aware of my learners' cultural sensitivities. & 4 & 3.3 & 3 & 2.5 & 9 & 7.5 & 37 & 30.8 & 67 & 55.8 \\
\hline & I can adapt to new policy changes at the ELI. & 1 & 0.8 & 6 & 5.0 & 9 & 7.5 & 39 & 32.5 & 65 & 54.2 \\
\hline & $\begin{array}{l}\text { I learn from my colleagues who come from } \\
\text { diverse cultural and academic backgrounds. }\end{array}$ & 3 & 2.5 & 7 & 5.8 & 16 & 13.3 & 39 & 32.5 & 55 & 45.8 \\
\hline & $\begin{array}{l}\text { I know how the English language is perceived in } \\
\text { Saudi Arabian society. }\end{array}$ & 3 & 2.5 & 3 & 2.5 & 10 & 8.3 & 40 & 33.3 & 64 & 53.3 \\
\hline & I can develop a good rapport with my learners. & 2 & 1.7 & 4 & 3.3 & 11 & 9.2 & 20 & 16.7 & 83 & 69.2 \\
\hline
\end{tabular}

Note. $\mathrm{S} . \mathrm{D}=$ Strongly Disagree, $\mathrm{S} . \mathrm{A}=$ Strongly Agree.

Table 3. Teachers' collegial cooperation before and after the CET

\begin{tabular}{|c|c|c|c|c|c|c|c|c|c|c|c|}
\hline & \multirow{2}{*}{$\begin{array}{l}\text { Collegial Cooperation } \\
\text { Before/After }\end{array}$} & \multicolumn{2}{|c|}{ S.D } & \multicolumn{2}{|c|}{ Disagree } & \multicolumn{2}{|c|}{ Neutral } & \multicolumn{2}{|c|}{ Agree } & \multicolumn{2}{|c|}{ S.A } \\
\hline & & $\mathrm{n}$ & $\%$ & $\mathrm{n}$ & $\%$ & $\mathrm{n}$ & $\%$ & $\mathrm{n}$ & $\%$ & $\mathrm{n}$ & $\%$ \\
\hline \multirow{3}{*}{ Before } & $\begin{array}{l}\text { It is important for me to seek my colleagues' help } \\
\text { in solving my pedagogical issues. }\end{array}$ & 3 & 2.5 & 14 & 11.7 & 34 & 28.3 & 49 & 40.8 & 20 & 16.7 \\
\hline & $\begin{array}{l}\text { Our professional discussions lead to enhance } \\
\text { students' learning outcomes. }\end{array}$ & 4 & 3.3 & 14 & 11.7 & 28 & 23.3 & 42 & 35.0 & 32 & 26.7 \\
\hline & $\begin{array}{l}\text { The ELI encourages teachers' professional } \\
\text { interaction. }\end{array}$ & 6 & 5.0 & 17 & 14.2 & 27 & 22.5 & 34 & 28.3 & 36 & 30.0 \\
\hline \multirow{3}{*}{ After } & $\begin{array}{l}\text { It is important for me to seek my colleagues' help } \\
\text { in solving my pedagogical issues. }\end{array}$ & 4 & 3.3 & 8 & 6.7 & 20 & 16.7 & 41 & 34.2 & 47 & 39.2 \\
\hline & $\begin{array}{l}\text { Our professional discussions lead to enhance } \\
\text { students' learning outcomes. }\end{array}$ & 4 & 3.3 & 8 & 6.7 & 13 & 10.8 & 37 & 30.8 & 58 & 48.3 \\
\hline & $\begin{array}{l}\text { The ELI encourages teachers' professional } \\
\text { interaction. }\end{array}$ & 7 & 5.8 & 10 & 8.3 & 17 & 14.2 & 21 & 17.5 & 65 & 54.2 \\
\hline
\end{tabular}

Table 4. Teachers' classroom practices before and after the CET

\begin{tabular}{|c|c|c|c|c|c|c|c|c|c|c|c|}
\hline & \multirow{2}{*}{$\begin{array}{l}\text { Classroom practice } \\
\text { Before/After }\end{array}$} & \multicolumn{2}{|c|}{ S.D } & \multicolumn{2}{|c|}{ Disagree } & \multicolumn{2}{|c|}{ Neutral } & \multicolumn{2}{|c|}{ Agree } & \multicolumn{2}{|c|}{ S.A } \\
\hline & & $\mathrm{n}$ & $\%$ & $\mathrm{n}$ & $\%$ & $\mathrm{n}$ & $\%$ & $\mathrm{n}$ & $\%$ & $\mathrm{n}$ & $\%$ \\
\hline \multirow{4}{*}{ Before } & $\begin{array}{l}\text { I can adapt the teaching methodologies according to } \\
\text { the contextual requirements. }\end{array}$ & 3 & 2.5 & 8 & 6.7 & 18 & 15.0 & 48 & 40.0 & 43 & 35.8 \\
\hline & $\begin{array}{l}\text { I adhere to the principles of communicative language } \\
\text { teaching. }\end{array}$ & 2 & 1.7 & 8 & 6.7 & 16 & 13.3 & 48 & 40.0 & 46 & 38.3 \\
\hline & $\begin{array}{l}\text { I am aware that differentiated instruction caters to the } \\
\text { needs and styles of different learners in mixed-ability } \\
\text { classes. }\end{array}$ & 3 & 2.5 & 13 & 10.8 & 27 & 22.5 & 51 & 42.5 & 26 & 21.7 \\
\hline & I am confident of my classroom management skills. & 3 & 2.5 & 5 & 4.2 & 17 & 14.2 & 37 & 30.8 & 58 & 48.3 \\
\hline \multirow{4}{*}{ After } & $\begin{array}{l}\text { I can adapt the teaching methodologies according to } \\
\text { the contextual requirements. }\end{array}$ & 2 & 1.7 & 3 & 2.5 & 11 & 9.2 & 30 & 25.0 & 74 & 61.7 \\
\hline & $\begin{array}{l}\text { I adhere to the principles of communicative language } \\
\text { teaching. }\end{array}$ & 2 & 1.7 & 4 & 3.3 & 11 & 9.2 & 31 & 25.8 & 72 & 60.0 \\
\hline & $\begin{array}{l}\text { I am aware that differentiated instruction caters to the } \\
\text { needs and styles of different learners in mixed-ability } \\
\text { classes. }\end{array}$ & 2 & 1.7 & 3 & 2.5 & 11 & 9.2 & 24 & 20.0 & 80 & 66.7 \\
\hline & I am confident of my classroom management skills. & 3 & 2.5 & 2 & 1.7 & 8 & 6.7 & 27 & 22.5 & 80 & 66.7 \\
\hline
\end{tabular}


Table 5. Teachers' self-efficacy before and after the CET

\begin{tabular}{|c|c|c|c|c|c|c|c|c|c|c|c|}
\hline & \multirow{2}{*}{$\begin{array}{l}\text { Self-efficacy } \\
\text { Before/After }\end{array}$} & \multicolumn{2}{|c|}{ S.D } & \multicolumn{2}{|c|}{ Disagree } & \multicolumn{2}{|c|}{ Neutral } & \multicolumn{2}{|c|}{ Agree } & \multicolumn{2}{|c|}{ S.A } \\
\hline & & $\mathrm{n}$ & $\%$ & $\mathrm{n}$ & $\%$ & $\mathrm{n}$ & $\%$ & $\mathrm{n}$ & $\%$ & $\mathrm{n}$ & $\%$ \\
\hline \multirow{5}{*}{ Before } & $\begin{array}{l}\text { I can influence my learners' academic } \\
\text { achievements. }\end{array}$ & 4 & 3.3 & 8 & 6.7 & 29 & 24.2 & 38 & 31.7 & 41 & 34.2 \\
\hline & I can get through difficult teaching situations. & 2 & 1.7 & 7 & 5.8 & 16 & 13.3 & 50 & 41.7 & 45 & 37.5 \\
\hline & $\begin{array}{l}\text { I seek my colleagues' and academic coordinators' } \\
\text { feedback on my classroom practices. }\end{array}$ & 5 & 4.2 & 14 & 11.7 & 34 & 28.3 & 46 & 38.3 & 21 & 17.5 \\
\hline & $\begin{array}{l}\text { I follow my mentor(s) for improving my } \\
\text { teaching. }\end{array}$ & 10 & 8.3 & 11 & 9.2 & 32 & 26.7 & 45 & 37.5 & 22 & 18.3 \\
\hline & I enjoy teaching EFL. & 3 & 2.5 & 4 & 3.3 & 17 & 14.2 & 41 & 34.2 & 55 & 45.8 \\
\hline \multirow{5}{*}{ After } & $\begin{array}{l}\text { I can influence my learners' academic } \\
\text { achievements. }\end{array}$ & 3 & 2.5 & 6 & 5.0 & 16 & 13.3 & 34 & 28.3 & 61 & 50.8 \\
\hline & I can get through difficult teaching situations. & 1 & 0.8 & 4 & 3.3 & 8 & 6.7 & 33 & 27.5 & 74 & 61.7 \\
\hline & $\begin{array}{l}\text { I seek my colleagues' and academic coordinators' } \\
\text { feedback on my classroom practices. }\end{array}$ & 5 & 4.2 & 11 & 9.2 & 19 & 15.8 & 42 & 35.0 & 43 & 35.8 \\
\hline & $\begin{array}{l}\text { I follow my mentor(s) for improving my } \\
\text { teaching. }\end{array}$ & 10 & 8.3 & 9 & 7.5 & 22 & 18.3 & 34 & 28.3 & 45 & 37.5 \\
\hline & I enjoy teaching EFL. & 3 & 2.5 & 3 & 2.5 & 16 & 13.3 & 31 & 25.8 & 67 & 55.8 \\
\hline
\end{tabular}

Table 6. Teachers' agency before and after the CET

\begin{tabular}{|c|c|c|c|c|c|c|c|c|c|c|c|}
\hline & \multirow{2}{*}{$\begin{array}{l}\text { Agency } \\
\text { Before/After }\end{array}$} & \multicolumn{2}{|c|}{ S.D } & \multicolumn{2}{|c|}{ Disagree } & \multicolumn{2}{|c|}{ Neutral } & \multicolumn{2}{|c|}{ Agree } & \multicolumn{2}{|c|}{ S.A } \\
\hline & & $\mathrm{n}$ & $\%$ & $\mathrm{n}$ & $\%$ & $\mathrm{n}$ & $\%$ & $\mathrm{n}$ & $\%$ & $\mathrm{n}$ & $\%$ \\
\hline \multirow{5}{*}{ Before } & $\begin{array}{l}\text { The ELI seeks my input in curriculum and } \\
\text { syllabus designing. }\end{array}$ & 18 & 15.0 & 12 & 10.0 & 41 & 34.2 & 34 & 28.3 & 15 & 12.5 \\
\hline & $\begin{array}{l}\text { I am free to use my supplementary materials to } \\
\text { enhance student learning. }\end{array}$ & 10 & 8.3 & 18 & 15.0 & 29 & 24.2 & 45 & 37.5 & 18 & 15.0 \\
\hline & $\begin{array}{l}\text { The ELI seeks my opinion regarding the contents } \\
\text { and modes of my professional development. }\end{array}$ & 15 & 12.5 & 18 & 15.0 & 45 & 37.5 & 33 & 27.5 & 9 & 7.5 \\
\hline & $\begin{array}{l}\text { I am free to choose my professional learning } \\
\text { pathways. }\end{array}$ & 7 & 5.8 & 10 & 8.3 & 36 & 30.0 & 47 & 39.2 & 20 & 16.7 \\
\hline & $\begin{array}{l}\text { I can implement the techniques and methods } \\
\text { learned during professional development } \\
\text { sessions. }\end{array}$ & 4 & 3.3 & 8 & 6.7 & 24 & 20.0 & 52 & 43.3 & 32 & 26.7 \\
\hline \multirow{5}{*}{ After } & $\begin{array}{l}\text { The ELI seeks my input in curriculum and } \\
\text { syllabus designing. }\end{array}$ & 19 & 15.8 & 10 & 8.3 & 31 & 25.8 & 35 & 29.2 & 25 & 20.8 \\
\hline & $\begin{array}{l}\text { I am free to use my supplementary materials to } \\
\text { enhance student learning. }\end{array}$ & 12 & 10.0 & 15 & 12.5 & 26 & 21.7 & 39 & 32.5 & 28 & 23.3 \\
\hline & $\begin{array}{l}\text { The ELI seeks my opinion regarding the contents } \\
\text { and modes of my professional development. }\end{array}$ & 16 & 13.3 & 18 & 15.0 & 28 & 23.3 & 35 & 29.2 & 23 & 19.2 \\
\hline & $\begin{array}{l}\text { I am free to choose my professional learning } \\
\text { pathways. }\end{array}$ & 10 & 8.3 & 8 & 6.7 & 27 & 22.5 & 43 & 35.8 & 32 & 26.7 \\
\hline & $\begin{array}{l}\text { I can implement the techniques and methods } \\
\text { learned during professional development } \\
\text { sessions. }\end{array}$ & 5 & 4.2 & 5 & 4.2 & 17 & 14.2 & 29 & 24.2 & 64 & 53.3 \\
\hline
\end{tabular}

Response rate and frequencies for five determinants of TPI before and after the test are shown in from Table 2 to Table 6. Results show a marked increase in item-level scores from before the test scores and after the test scores. By looking at the descriptive statistics, all the TPI attributes have changed from the pre-score to the post score. Nevertheless, the changes occurred in the agency are less obvious as compared to the changes in the other four constructs. To further determine whether these differences were statistically significant, Wilcoxon signed rank test was applied to calculate the significance of the identified differences (before-after) of each survey item for all five attributes.

\subsection{Assumptions}

A two-tailed Kolmogorov-Smirnov test was applied to determine whether or not it meets the normality assumption. Since the $\mathrm{p}<0.05$ so not enough evidence leads to the rejection of null hypothesis; therefore, the hypothesis of normality is rejected. Hence all the variables are non-normal suggesting the application of 
non-parametric tests. The Wilcoxon Signed Rank test is a non-parametric test, an equivalent of the paired sample t-test is based on the assumption that the data is not normally distributed.

Table 7. The normality test

\begin{tabular}{llll}
\hline Pre and Post Variables & $\mathrm{N}$ & Kolmogorov-Smirnov Z & Sig. (2-tailed) \\
\hline Context before & 120 & 2.314 & .000 \\
Context after & 120 & 2.091 & .000 \\
Collegial cooperation before & 120 & 1.711 & .006 \\
Collegial cooperation_after & 120 & 2.087 & .000 \\
Classroom Practice_before & 120 & 2.162 & .000 \\
Classroom Practice after & 120 & 2.683 & .000 \\
Self-efficacy_before & 120 & 1.776 & .004 \\
Self-efficacy_after & 120 & 1.710 & .006 \\
Agency_before & 120 & 1.426 & .034 \\
Agency_after & 120 & 1.396 & .041 \\
\hline
\end{tabular}

As shown in Table 7, the p-values of all the studies variables are less than 0.05 , which points out that there is no enough evidence to accept the null hypothesis. Therefore, there is a statistically significant difference between the TPI before and after they participated in the CET course, as shown in Table 8.

Table 8. Test statistics

\begin{tabular}{lcc}
\hline & S & Sig. (2-tailed) \\
\hline Context_post - Context_pre & $-5.472^{\mathrm{b}}$ & .000 \\
Collegial_cooperation_post - Collegial_cooperation_pre & $-6.019^{\mathrm{b}}$ & .000 \\
Classroom_Practice_post - Classroom_Practice_pre & $-7.051^{\mathrm{b}}$ & .000 \\
Self_efficacy_post - Self_efficacy_pre & $-5.569^{\mathrm{b}}$ & .000 \\
Agency_post - agency_pre & $-4.883^{\mathrm{b}}$ & .000
\end{tabular}

a. Wilcoxon Signed Ranks Test

b. Based on negative ranks.

Wilcoxon signed rank test was used to evaluate the significance of the difference between the before and after the score. The differences showed a statistically significant improvement in the after score compared to the before $(p<.001$, two-tailed). Therefore, the results of the Wilcoxon signed rank test rejects the null hypothesis and accepts that there are significant differences between the before and after the scores of the five attributes of EFL TPI in relation to in-service professional development.

\subsection{Association (Correlation) Among the Five Professional Identity Dimensions}

The current study is exploratory in nature and is not correlational one; however, since no single study has investigated the five TPI attributes together, to understand the interrelationship of these five attributes, the association among them is studied. Through correlation coefficients the association among the attributes is determined. Correlation coefficients, $r$, range from 0 to 1 to -1 ; where 0 indicates no relationship, 1 perfect positive linear relationship, and -1 perfect negative linear relationship. Positive relationship shows if one variable increases the other also increases and vice versa. According to Cohen's (2013) standards, 0.10 represents weak association, 0.30 a moderate association, and 0.50 a strong association among the variables. Figure 2 shows the correlations among all the five attributes are above 0.50 indicating a strong association. 

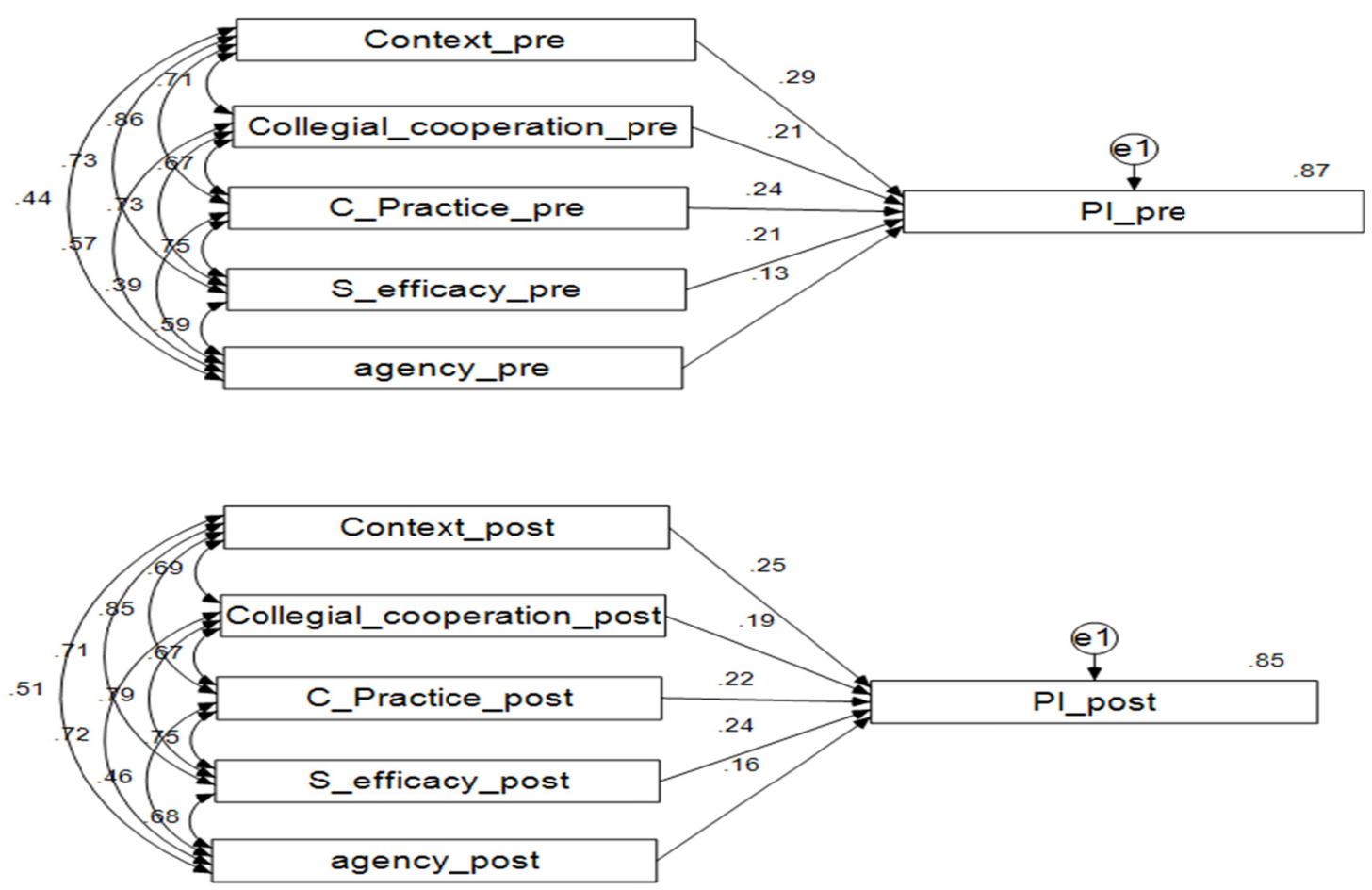

Figure 2. Association among five attributes pre and post

A significant identity change was observed between the pre and post scores; however, to determine how much change is attributed to the PI $R^{2}$ is considered. $R^{2}$ calculates what percent of the change is accounted for by the independent variables. For the current study $R^{2}$ is 0.85 i.e. $85 \%$ of the overall change in PI is attributable to the five attributes. Moreover, to identify the relative importance of the five attributes beta coefficients are to be considered. The higher the beta coefficient value of a variable the greater is its impact and vice versa. From Figure 1 it is evident that context has the maximum impact followed by $\mathrm{CP}$ while Agency has the minimum impact on PI of teachers

\section{Discussion}

The findings of this study suggest that the Cambridge English Teachers (CET), an in-service professional development program at an English language institute of a Saudi Arabian public university has significantly influenced the EFL TPI. This study confirms what other researchers have found out that any form of professional learning whether institutional or extra-institutional has transformed the participants', i.e. EFL instructors' professional and personal selves in educational settings in more than one ways (Alsalahi, 2015; Abedina, 2012; Pennington and Richards, 2016; Riyanti, 2017; Spence, 2016). All five attributes of EFL TPI i.e., context, collegial cooperation, classroom practices, self-efficacy, and agency have changed considerably. These attributes are considered as EFL teachers' dimensions of experiences during learning. Thus, this study appears to be the first to explore EFL teachers' identity attributes, their relationship among each other, and how they were transformed during an institutional PD program.

First, this study shows that the participants' knowledge of the teaching context has widened due to their involvement in the PD course. Consistent with our present findings, Dejaeghere and Cao (2009) explored learning about the teaching context that takes place through school-based PD programs, in which the courses guide the process of intercultural and socio-cultural contextual knowledge development. However, the current study not only looked into the intercultural competence development of the teachers but also focused on the teachers' awareness of learners' culture. Based on Clandinin and Connelly's (1995) knowledge landscape metaphor, besides the content and pedagogical knowledge, teacher knowledge of the educational context has a pervasive impact on all his professional vistas, from beliefs to classroom practices to student achievements. This result might be beneficial for the teacher trainers to consider focusing on the teachers' awareness of the learners' and institutional context knowledge, especially in Saudi Arabia where conservative norms prevail among the 
students as well as the faculty members.

As learning is steeped in dialogue, a significant change occurred, according to the findings of this study, in teachers' collegial cooperation as a result of the CET course. Our findings complement and extend the recent work by Tariq and Jumani (2016), who suggested the role of in-service PD in strengthening teacher collaboration. Teacher professional collaboration is based on the premise that learning is a socially constructed phenomenon. From this perspective, the centrality of teacher collaboration, i.e., the culture of sharing knowledge should be a natural outcome of any PD effort. Therefore, to overcome the teaching and classroom management challenges in Saudi EFL context, where there are mixed ability classes and unmotivated learners, collegial cooperation fostering should be included in PD courses.

Our next finding was that the CET course improved the teachers' classroom practices and performance by developing their teaching philosophy, teaching expertise, and classroom management skills. It was shown that by applying the newly learned pedagogical knowledge in the PD, the students learning outcomes were improved. A recent study in the UAE by Badari, Alnuaimi, Yang, Al Rashid and Sumaiti (2017) has also indicated that the impact of PD is directly related to change in teachers' beliefs, attitudes, and teaching practices. Teachers' classroom practices development through PD fits with findings by Giraldo (2014), who elaborates that after the PD programs teachers significantly improved their classroom performance as their classroom practices became more communicative, student-centered and reflective. This suggests that PD may hone the teachers' classroom performance by bridging the theory-practice gap.

Another finding of this study is that the CET caused a positive shift in the TSE of the participants. This is supported by Hasty's (2015) study which explored a positive correlation between TSE and participation in professional development. In contrast, other research (e.g. Garet \& Porter, 2001) recognizes that initial PD endeavors cannot cause a long-term shift in teacher self-efficacy. In fact, teacher self-efficacy being one of the most important factors in TPI is less likely to develop in general and short-term PD programs, such as attending workshops, seminars or small one-shot course. Therefore, it is suggested that PD programs should be designed after a thorough need analysis of teachers' professional requirement.

Our last finding is that teacher agency seems nested in PD experiences, as the CET played a role in the enhancement of the EFL teacher agency; however, of the five attributes it is the least affected one. Among the situated educational practices, the agency appears the most complex one owing to the ongoing tension whether teacher agency supports or challenges the institutional control and structure. Some perceive teacher agency as a blow to the data-driven evidence-based teaching approaches implemented by institutions while others see it as an indispensable factor of teaching (Biesta, Priestly, \& Robinson, 2015). Our findings support what Noonan (2016) purported that teachers improve their agency in PD by choosing the method and material they have learned during PD which they deem appropriate in their teaching context. While teacher agency directly impacts students' learning, teacher trainers and policymakers should consider teachers' opinions in syllabus designing, professional development, and classroom methods and methodologies. Nonetheless, the institutes' decision on the aforesaid issues should be final for standardizing teaching practices in a large institute such as the ELI.

\section{Conclusion}

In this study, we analyzed the TPI in a Saudi Arabian EFL context developed as a result of an in-service PD program. For the purpose of this study EFL TPI is defined as a sum total of the knowledge of teaching context, collegial collaboration, teaching practices, teacher self-efficacy, and teacher agency. The statistical analysis indicated that knowledge of context, TSE and classroom practices showed larger changes; whereas changes were moderate for collegial cooperation and smaller for agency. To gain a deeper insight the qualitative phase of this study will elaborate on the changes occurred as this study is part of a larger mixed method project. While it is a fact that student learning outcomes are directly related to teacher professional identity, our findings show that teacher identity is evolved during PD learning. Future research is warranted to provide insight into the impact of the re-constituted TPI on the students' learning outcomes. Furthermore, to know whether the changes are perceived positively or negatively by the higher administration, the academic coordinators, the lead managers, unit heads and vice deans' perceptions should also be investigated.

\section{Limitations}

A couple of limitations have been identified which may constrain the generalizability of the study. The first one is that due to gender segregation policy implemented at the ELI only male EFL teachers participated in the study. To enhance the generazability of study, future research might consider replicating the study with female EFL teachers at the ELI. The second limitation deals with social desirability bias since the researcher is an academic coordinator at the ELI and respondents could have answered the questions in a manner which may be viewed 
favorable by the administration. Had the questionnaire been conducted by an instructor, the results might have been different.

\section{References}

Abednia, A. (2012). Teachers' professional identity: Contributions of a critical EFL teacher education course in Iran. Teaching and Teacher Education, 28(5), 706-717. https://doi.org/10.1016/j.tate.2012.02.005

Ahmad, H (2015). Investigating The Factors Which Influence the Professional Identity of Pakistani EFL Teachers At A Saudi Arabian Public University. (Unpublished Master thesis). University of Sunderland, UK.

Alsalahi, S. M. (2015). Stages of Teacher's Professionalism: How Are English Language Teachers Engaged? Theory and Practice in Language Studies, 5(4), 671. https://doi.org/10.17507/tpls.0504.01

Alvesson, M., Ashcraft, K. L., \& Thomas, R. (2008). Identity matters: Reflections on the construction of identity scholarship in organization studies. Organization, 15(1), 5e28. https://doi.org/10.1177/1350508407084426

Badri, M., Alnuaimi, A., Yang, G., Rashidi, A. A., \& Sumaiti, R. A. (2017). A Structural Equation Model of Determinants of the Perceived Impact of Teachers' Professional Development-The Abu Dhabi Application. SAGE Open, 7(2), 215824401770219. https://doi.org/10.1177/2158244017702198

Bandura, A. (1977). Self-efficacy: Toward a unifying theory of behavioral change. Psychological Review, 84(2), 191-215. https://doi.org/10.1037/0033-295X.84.2.191

Bandura, A. (1993). Perceived Self-Efficacy in Cognitive Development and Functioning. Educational Psychologist, 28(2). https://doi.org/10.1207/s15326985ep2802_3

Bandura, A. (1997). Self-efficacy: the exercise of control. New York: W.H. Freeman

Bandura, A. (1998). Personal and collective efficacy in human adaptation and change. In J. G. Adair, D. B. Belanger, \& K. L. Dion (Eds.), Advances in psychological science (Vol. 1, pp. 51-71). Hove, UK: Psychology Press.

Barkhuizen, G. (2017). Reflections on language teacher identity research. New York: Routledge, Taylor \& Francis Group.

Biesta, G., Priestley, M., \& Robinson, S. (2015). The role of beliefs in teacher agency. Teachers and Teaching: theory and practice, 21(6), 624-640. https://doi.org/10.1080/13540602.2015.1044325

Borg, M. (2017). Identity and Teacher Research. In G. Barkhuizen (Ed.), Reflections on language teacher identity research. Routledge. New York.

Campbell, D. T., \& Stanely, J. C. (1963). Experimental and quasi-experimental designs for research. Houghton Mifflin Company Boston.

Cheng, L. (2004). Understanding challenges faced by Chinese teachers of English. Teaching English as a Second Language, 7(4), 1-14.

Clandinin, D. J., \& Connelly, F. M. (1996). Teachers Professional Knowledge Landscapes: Teacher Stories. Stories of Teachers. School Stories. Stories of Schools. Educational Researcher, 25(3), 24. https://doi.org/10.3102/0013189X025003024

Clarke, M. (2008). Language teacher identities: Co-constructing discourse and community: New perspectives on language and education. New York: Multilingual Matters. https://doi.org/10.21832/9781847690838

Danielewicz, J. (2001). Teaching selves. New York: State University of New York Press.

Datnow, A. (2002). What Can We Learn from Educational Reform? Education in the Asia-Pacific Region: Issues, Concerns And Prospects Secondary Education at the Crossroads, 1-14.

Dejaeghere, J. G., \& Cao, Y. (2009). Developing U.S. teachers' intercultural competence: Does professional development matter? International Journal of Intercultural Relations, 33(5), 437-447. https://doi.org/10.1016/j.ijintrel.2009.06.004

Desimone, L. (2009). Improving impact studies of teachers' professional development: Towards better $\begin{array}{llll}\text { conceptualizations and } & \text { Educational Reasures. }\end{array}$ https://doi.org/10.3102/0013189X08331140

Driel, J. H. V., \& Berry, A. (2012). Teacher professional development focusing on pedagogical content knowledge. Educational Researcher, 41(1), 26-28. https://doi.org/10.3102/0013189X11431010 
Duranti, A. (2004/2006). Agency in language. In A. Duranti (Ed.), A companion to linguistic anthropology (pp. 451-473). Malden, MA: Blackwell.

Fareh, S. (2010). Challenges of teaching English in the Arab world: Why can't EFL programs deliver as expected? Procedia-Social and Behavioral Sciences, 2(2). https://doi.org/10.1016/j.sbspro.2010.03.559

Freeman, D. (1989). Teacher training, development, and decision making: A model of teaching and related strategies for language teacher education. TESOL Quarterly, 23(1), 27-45. https://doi.org/10.2307/3587506

Garet, M. S., Porter, A. C., Desimone, L., Birman, B. F., \& Yoon, K. S. (2001). What Makes Professional Development Effective? Results From a National Sample of Teachers. American Educational Research Journal, 38(4), 915-945. https://doi.org/10.3102/00028312038004915

Garton, S., \& Richards, K. (Eds.). (2008). Professional encounters in TESOL: Discourses of teachers in teaching. Basingstoke: Palgrave Macmillan. https://doi.org/10.1057/9780230594173

Giraldo, F. (2014). The Impact of a Professional Development Program on English Language Teachers' Classroom Performance. PROFILE Issues in Teachers Professional Development, 16(1), 63-76. https://doi.org/10.15446/profile.v16n1.38150

Grodsky, E., \& Gamoran, A. (2003). The Relationship Between Professional Development and Professional Community in American Schools. School Effectiveness and School Improvement, 14(1), 1-29. https://doi.org/10.1076/sesi.14.1.1.13866

Guskey, T. (2000). Evaluating professional development. Thousand Oaks, CA: Corwin Press.

Hofman, R. H., \& Dijkstra, B. J. (2010). Effective teacher professionalization in networks? Teaching and Teacher Education, 26(4), 1031-1040. https://doi.org/10.1016/j.tate.2009.10.046

Hoogstraten, J. (1982). The Retrospective Pretest in an Educational Training Context. The Journal of Experimental Education, 50(4), 200-204. https://doi.org/10.1080/00220973.1982.11011824

Ingvarson, L., Meiers, M., \& Beavis, A. (2005). Factors affecting the impact of professional development programs on teachers' knowledge, practice, student outcomes \& efficacy. Education Policy Analysis Archives, 13, 10. https://doi.org/10.14507/epaa.v13n10.2005

Johnson, K. E. (2009). Second language teacher education: A sociocultural perspective. London: Routledge. https://doi.org/10.1007/s10972-009-9134-y

Johnston, B. (1997). Do EFL teachers have careers? TESOL Quarterly, 31, 681-712. https://doi.org/10.2307/3587756

Karatas (2015) Challenges, professional development, and professional identity: a case study on novice language teachers. (Unpublished Master thesis). Middle East Technical University, Northern Cyprus campus.

Kelchtermans, G. (2009). Who I am in how I teach is the message: Self-understanding, vulnerability and reflection. Teachers and Teaching, 15, 257-272. https://doi.org/10.1080/13540600902875332

Kramsch, C., \& Sullivan, P. (1996). Appropriate pedagogy. ELT Journal, 50(3), 199-212. https://doi.org/10.1093/elt/50.3.199

Lamb, T. A., \& Tschillard, R. (2005). Evaluating learning in professional development workshops: Using the retrospective pretest. Journal of Research in Professional Learning.

Lave, J., \& Wenger, E. (1991). Situated Learning. Cambridge: Cambridge University Press. https://doi.org/10.1017/CBO9780511815355

Marcelo, C. (2009). Professional development of teachers: past and future. Educational Sciences Journal, 08, 5-20.

Miller, J. (2009). Teacher identity. In A. E. Burns \& J. C. Richards (Eds.), The Cambridge Guide to Second Language Teacher Education. New York: Cambridge University Press.

Moore, D., \& Tananis, C. A. (2009). Measuring Change in a Short-Term Educational Program Using a Retrospective Pretest Design. American Journal of Evaluation, 30(2), 189-202. https://doi.org/10.1177/1098214009334506

Mora, A., Trejo, P., \& Roux, R. (2014). English language teachers' professional development and identities. PROFILE Issues in Teachers' Professional Development, 16(1), 49-62. 
https://doi.org/10.15446/profile.v16n1.38153

Neilson, R. (2011). Moments of disruption and the development of expatriate. TESOL teachers English Australia Journal, 27(1), 18-32

Nesje, K., Canrinus, E. T., \& Strype, J. (2018). "Trying on teaching for fit" - Development of professional identity among professionals with multiple career opportunities. Teaching and Teacher Education, 69, 131-141. https://doi.org/10.1016/j.tate.2017.10.011

Noonan, J. (2016). Teachers Learning: Engagement, Identity, and Agency in Powerful Professional Development (Unpublished master's thesis). Culture, Communities, and Education, Harvard Graduate School of Education, November.

Norton, B. (2001). Non-participation, imagined communities, and the language classroom. In M. Breen (Ed.), Learner contributions to language learning: New directions in research (pp. 159-171). London: Pearson Education Limited.

Onafowora, L. (2005). Teacher Efficacy Issues in the Practice of Novice Teachers. Educational Research Quarterly 28(4), 34-43.

Pennington M. C., \& Richards J. C. (2016). Teacher Identity in Language Teaching: Integrating Personal, Contextual, and Professional Factors. RELC Journal, 47(1), 5-23. https://doi.org/10.1177/0033688216631219

Pratt, C. C., McGuigan, W. M., \& Katzev, A. R. (2000). Measuring Program Outcomes:Using Retrospective Pretest Methodology. American Journal of Evaluation, 21(3), 341. https://doi.org/10.1016/S1098-2140(00)00089-8

Princess Nourah University's English Language program soars to new heights. (2017, June 27). Retrieved from http://www.arabnews.com.

Riaynti, D. (2016). Teacher Identity Development: A Collective Case Study Of English As A Foreign Language Pre-Service Teachers Learning to Teach In An Indonesian University Teacher Education Program. (Unpublished $\mathrm{PhD}$ thesis). The Graduate College at the University of Nebraska.

Richards J. C. (2012). Competence and performance in language teaching. In A. Burns \& J. C. Richards (Eds.), The Cambridge Guide to Pedagogy and Practice in Second Language Teaching (pp. 46-59). New York: Cambridge University Press.

Richards, J. C. (2011). Competence and performance in language teaching. Cambridge: Cambridge University Press.

Richards, J. C. (2017). Teacher identity in second language teacher education. In G. Barkhuizen (Ed.), Reflections on language teacher identity research. New York: Routledge.

Robinson, W. (2014). A Learning Profession? Teachers and their Professional Development in England and Wales 1920-2000. Rotterdam: Sense.

Rodgers, C. R., \& Scott, K. H. (2008). The development of the personal self and professional identity in learning to teach. In M. Cochran-Smith, S. Feiman-Nemser, D. J. Mclntyre, \& K. E. Demers (Eds.), Handbook on research in teacher education (3rd ed., pp. 232-755). New York: Routledge.

Ronnie, D. (2013). The professional identity of teacher educators: Career on the cusp. London: Routledge.

Russ-Eft, D. F., \& Preskill, H. S. (2009). Evaluation in organizations: a systematic approach to enhancing learning, performance, and change. New York: Basic Books.

Sarason, S. B. (1996). Revisiting the culture of the school and the problem of change. New York: Teachers College Press.

Singh, G., \& Richards, J. C. (2006). Teaching and learning in the language teacher education course room: A critical sociocultural perspective. RELC Journal, 37(2), 149-175. https://doi.org/10.1177/0033688206067426

Smagorinsky, P., Cook, L. S., Moore, C., Jackson, A. Y., \& Fry, P. G. (2004). Tensions in Learning to Teach. Journal of Teacher Education, 55(1), 8-24. https://doi.org/10.1177/0022487103260067

Spence, C. J. (2016). Impact of Professional Development in Response to Intervention on Secondary Teachers' Efficacy. (Unpublished PhD thesis). College of Education, Walden University. 
Sulaimani, A., \& Elyas, T. (2015). A Critical Review of the CELTA Syllabus Within the Context of Saudi Arabia. Romanian Journal of English Studies, 12(1). https://doi.org/10.1515/rjes-2015-0003

Tariq, M. A., \& Jumani, N. (2015). A Study to Investigate the Effectiveness of In-Service Training of Teachers for the Collaborative Practices. Mediterranean Journal of Social Sciences. https://doi.org/10.5901/mjss.2016.v7n1p480

Vähäsantanen, K. (2015). Professional agency in the stream of change: understanding educational change and teachers' professional identities. Teaching and Teacher Education, 47, 1-12. https://doi.org/10.1016/j.tate.2014.11.006

Van Huizen, P., Van Oers, B., \&Wubbels, T. (2005). Vygotskian Perspective on Teacher Education. Journal of Curriculum Studies, 37(3), 269-290. https://doi.org/10.1080/0022027042000328468

Watson, C. (2006). Narratives of practice and the construction of identity in teaching. Teachers and Teaching: Theory and Practice, 12(5), 509-526. https://doi.org/10.1080/13540600600832213

Yang, H. (2015). Teacher mediated agency in educational reform in china. Springer International. https://doi.org/10.1007/978-3-319-15925-6

Zahra, R. H. S., Mohammad, S. B., \& Lotfollah, Y. (2015). Promoting teacher professional development: the role of individual and contextual factors. International Journal of Applied Linguistics \& English Literatur, 4(1), 41.

\section{Copyrights}

Copyright for this article is retained by the author(s), with first publication rights granted to the journal.

This is an open-access article distributed under the terms and conditions of the Creative Commons Attribution license (http://creativecommons.org/licenses/by/4.0/). 